\title{
Global and regional estimates of dental pain among children and adolescents-systematic review and meta-analysis
}

\author{
Kalyana Chakravarthy Pentapati ${ }^{1}$ D $\cdot$ Sravan Kumar Yeturu ${ }^{2} \cdot$ Hanan Siddiq $^{1}$
}

Received: 30 January 2020 / Accepted: 7 June 2020 / Published online: 16 June 2020

(c) The Author(s) 2020

\begin{abstract}
Aim We aimed to evaluate the pooled prevalence of dental pain amongst children and adolescents.

Methods Studies conducted in children and adolescents up to18 years of age and where prevalence of dental is reported or calculated were included. Search was performed in four major databases from inception to June 1st, 2019. Prevalence estimate at the maximal recall for the dental pain for the individual study was used to calculate the overall pooled estimate. Results The prevalence of dental pain ranged from 1.33 to $87.8 \%$ in the included publications for quantitative synthesis $(n=97)$. More than half of the publications reported the lifetime prevalence of dental pain $(n=51)$ while few studies reported the current prevalence of dental pain $(n=3)$ and only one study evaluated the dental pain in the past one week. Heterogeneity was high among the included publications $\left(Q=49,063.12 ; P<0.001 ; \mathrm{df}=96\right.$ and $\left.I^{2}=99.8 ; P<0.001\right)$. Overall pooled prevalence of dental pain was $32.7(\mathrm{CI}=29.6-35.9)$. No difference was seen with respect to the trends in prevalence of dental pain (Coefficient: 0.005 ; 95\% CI - 0.001-0.011; $P$-value: 0.101 ).

Conclusion Two out of ten children below five years, four out of ten children between 6 and 12 years and three out of ten adolescents between 13 and 18 years would have experienced pain in the past. Overall, three out of ten children or adolescents might have experienced dental pain in the past. There was no difference in the pain prevalence between male and females. Studies from Africa reported highest pooled prevalence (50.1\%) with least being from Australia (20.7\%). Studies from India (40.4\%), China (41.3\%) and Iran (42.6\%) reported high pooled prevalence estimates of dental pain.
\end{abstract}

Keywords Adolescents $\cdot$ Children $\cdot$ Dental pain $\cdot$ Prevalence $\cdot$ Toothache

\section{Introduction}

Pain is defined as "an unpleasant sensory and emotional experience associated with actual or potential tissue damage, or described in terms of such damage (Treede 2018).” Pain is multidimensional in nature and consists of physiological and psychological variables linked with tissue damage (Santos et al. 2019). Despite considerable improvements in oral health care delivery, dental pain is acknowledged as a common symptom of oral disease (Goes et al. 2008). It is one of the major problems due to which individuals avail dental

Kalyana Chakravarthy Pentapati

drkalyan81@gmail.com; kalyan.cp@manipal.edu

1 Department of Public Health Dentistry, Manipal College of Dental Sciences, Manipal, Manipal Academy of Higher Education, Manipal 576104, Karnataka, India

2 Department of Public Health Dentistry, Amrita School of Dentistry, Amrita Viswavidya Peetham, Kochi, India treatment. It has a considerable impact on the daily activities of individuals like eating, sleeping, homework, paying attention in the class (Goes et al. 2008; Naidoo et al. 2013; Santos et al. 2019), school absenteeism (Ferraz et al. 2014; Ruff et al. 2019), playing, low academic achievement, (Ruff et al. 2019; Seirawan et al. 2012) and avoidance of particular foods which might trigger the pain. Similarly, parents of children having dental pain reported higher workplace absenteeism (Ribeiro et al. 2015b), increased expenditure (2016) and guilt (Gomes et al. 2014). In view of the potential impact of dental pain on oral health-related quality of life, reducing the prevalence of dental pain is included as one of the critical components in the Global Goals for Oral Health 2020 (Hobdell et al. 2003).

Many terminologies like dental pain, oral pain, facial pain, orofacial pain are used interchangeably. Oral pain refers to the pain within the mouth (Macfarlane et al. 2002) whereas dental pain refers to the "pain that originates from innervated tissues within the tooth or 
immediately adjacent to it (Gibbs and Hargreaves 2013)." "Facial pain (FP) includes pain whose origin is below the canthomeatal line, above the neck and anterior to the ears, while oral pain indicates that the pain is originating from structures within the mouth (Macfarlane et al. 2002)."

Studies have shown a direct relationship of dental pain with oral conditions like dental caries (Moura-Leite et al. 2008), abscess (Ferraz et al. 2014), and dentoalveolar trauma (Moure-Leite et al. 2011). Erupting teeth, as well as exfoliating primary teeth, have also shown to cause dental pain (Shepherd et al. 1999). The most consistent clinical correlate for the occurrence of dental pain is due to the advanced stage of dental caries, primarily in the lower socioeconomic groups with limited access to care (Slade 2001). Young children with dental caries are at risk of experiencing further dental pain (Levine et al. 2002). Even gingivitis has shown to cause dental pain in preschool children (Moura-Leite et al. 2008).

Neurophysiological processes, along with other factors (socio-demographic, cultural, and psychological), have an influential role in the perception of dental pain (Ratnayake and Ekanayake 2005). Adults and children have a different understanding of pain as well as health problems and their effect on oral health-related quality of life (Moura-Leite et al. 2008).

Dental pain was shown to be associated with poor oral health status and decreased access to oral health care which are considered as predictor or proxy indicator to evaluate the use of dental services (Ekanayake and Mendis 2002). Dental pain is a traumatic experience and often requires treatment. Hence, oral health professionals and researchers must understand associated physiological factors, pathological factors, intensity, severity and methods to avoid the dental pain. Considering the impact of dental pain on the individual and the community, it is necessary to understand the scope of this dental public health problem. Such an evaluation helps researchers and planners help to understand the impact of dental pain, frame policies, and the allocation of appropriate and valuable resources (Fernandes et al. 2019). Systematic reviews exist on various clinical oral conditions like caries (Al Agili 2013; Al Ayyan et al. 2018) and molar incisor hypomineralization (Pentapati et al. 2017) in children, dental pain and caries among children and adolescents (Slade 2001), dental pain (Pau et al. 2003) and root caries (Pentapati et al. 2019) in the adults. To date, there were no systematic reviews or meta-analysis on the subjective indicators like the self-reported prevalence of dental pain among children and adolescents. Hence, we aimed to evaluate the pooled prevalence of dental pain amongst children and adolescents.

\section{Materials and methods}

\section{Selection criteria}

Cohort or cross-sectional observational studies which reported period or point prevalence of dental pain among children and adolescents up to18 years of age in English language were included. Studies published as conference proceedings, editorials or letters were excluded.

\section{Search strategy}

Publications were identified by searching four databases (Pubmed, Scopus, Embase, and CINAHL) from inception to June 1 st, 2019. Search was performed using keywords and free text words based on the previous publications ("dental pain" OR "teeth pain" OR "tooth pain" OR "toothache" OR "teeth ache" AND "Prevalence" OR "Cross-sectional studies" OR "Epidemiology" OR "Epidemiologic methods" OR "Epidemiologic research design" OR "Epidemiologic studies" OR "Epidemiologic measurements" OR "Cohort studies") (Mansfield et al. 2016; Pentapati et al. 2019, 2017). Limits applied were children and adolescents up to 18 years of age, humans and English through filters provided by individual databases mentioned above. The studies were transferred to the Rayyan website (https://rayyan.qcri.org/) for the removal of duplicates and screened for titles and then abstracts by evaluators (PKC and YSK). Shortlisted publications were subjected to full-text screening by evaluators (PKC and YSK) to assess the eligibility. Discrepencies were resolved after appraisal by the third evaluator (HS).

\section{Assessment of risk of bias (ROB)}

All publications were appraised for ROB assessment using a nine item tool developed for prevalence studies (Hoy et al. 2012) by evaluators (YSK and HS and discrepancies were resolved by a third evaluator (PKC).

\section{Data extraction}

Two evaluators independently (YSK and PKC) performed the data extraction and any discrepancies were resolved by a third evaluator (HS). Details included were age, gender and geographic distribution, prevalence estimates as per gender, publication year, and prevalence estimates of dental pain (current, 1 week, 1, 3, 6, 12 months, and life-time experience).

\section{Statistical analysis}

Prevalence estimate at the maximal recall for the dental pain for each individual study was used to calculate the overall 
pooled estimate. $I^{2}$ stfatistic which serve as an measure of heterogeneity was calculated. Meta-analysis was performed using Open Meta software (Metafor Package 1.4).(1999) Random-effects model was used to calculate summary prevalence data and 95\% confidence intervals (DerSimonian and Laird 1986). Sub-group analysis was performed for variables like continent, gender, risk of bias and time recall of prevalence of dental pain. Meta-regression was performed to evaluate the trends in prevalence of dental pain and Funnel plot was used to assess publication bias (Sterne and Egger 2001).

\section{Results}

\section{Search results}

Our initial search resulted in 1814 publications. After the removal of duplicates, 1186 publications were screened for title and abstract. Full-text screening was performed for eligible publications $(n=196)$. Seventy seven publications were excluded due to inappropriate study design or unclear outcome $(n=74)$, wrong study population $(n=1)$, age of the included participants beyond 18 years $(n=5)$ and other languages $(n=2)$. One publication was included by manual searching of citation list. A total of 115 publications were included in the qualitative synthesis. Eighteen publications were later excluded (secondary data analysis of published studies), and 97 publications were included in the final metaanalysis (Table 1 and Fig. 1).

\section{Prevalence}

The prevalence of dental pain ranged from 1.33 to $87.8 \%$ (Ananthakrishnan et al. 2001; Naidoo et al. 2001). Sixteen publications reported a prevalence of more than $50 \%$ (Adeniyi and Odusanya 2017; Alzahrani 2019; Barreto et al. 2017; Bashirian et al. 2018; Dandi et al. 2011; Van Dijk et al. 2006; Hu et al. 2018; Jürgensen and Petersen 2011, 2009; Mishra et al. 2018; Naidoo et al. 2001; Oliveira et al. 2018; Santos et al. 2019; Shekhawat et al. 2016; Shidara et al. 2007; Soares et al. 2015). Only ten studies reported a prevalence of less than 10\% (Ananthakrishnan et al. 2001; Booth et al. 1992; Hardy et al. 2018; Karibe et al. 2015; Lemes et al. 2015; Rupali et al. 2010; Sarri et al. 2012; Siegal et al. 2004; Siqueira et al. 2013; Sousa et al. 2014) and 18 publications reported prevalence between 10 and 20\% (Bastos et al. 2008; Corrêa-Faria et al. 2018; Dogar et al. 2011; Du et al. 2011; Evans et al. 1995; Figueiredo et al. 2011; Goettems et al. 2018; Guskuma et al. 2017; Kamran et al. 2017; Kumar et al. 2014; Lewis and Stout 2010; Maharani et al. 2019; Misrohmasari et al. 2018; Perera and Ekanayake 2008;
Ratnayake and Ekanayake 2005; Treasure and Dever 1992; Vargas et al. 2005, 2002). There was high variability among the studies in the assessment of the prevalence of dental pain. The majority of the publications reported the lifetime prevalence of dental pain $(n=51)$, very few studies assessed the current prevalence of dental pain $(n=3)$ and only one study evaluated the dental pain in the past 1 week.

\section{Age}

There was no clear distinction in the age grouping of the children and adolescents for most of the publications. Eighteen publications reported prevalence of pain for children less than 5 years [18.5\% (95\% CI 14.7-22.4)], 25 publications reported for 6-12 [41.7\% (95\% CI 33.3-50.2)] years old and only nine publications reported for $13-18$ years old [25.8\% (95\% CI 14-37.5)]. Six studies reported prevalence among WHO index age group 5 years (Range: 12.66-34.93) [21.5\% (95\% CI 17.1-26)] (Carmichael et al. 1989; Evans et al. 1995; Ferreira-Júnior et al. 2015; Moura-Leite et al. 2008; Perazzo et al. 2017; Tsakos et al. 2012). Eight studies used the WHO index age groups 12 years (Range 12.09-71.4) [30.9\% (95\% CI 14.1-47.8)] (Andegiorgish et al. 2017; Bastos et al. 2008; Dandi et al. 2011; Guskuma et al. 2017; Jürgensen and Petersen 2009; Lopes et al. 2013; Robinson et al. 2005; Traebert et al. 2005), four studies reported prevalence among 12 and 15 years old (Kumar et al. 2016; Maharani et al. 2019; Peres et al. 2010; Shekhawat et al. 2016) [28.8\% (95\% CI 12.9-44.7)] and one study reported prevalence in 15 years old (Perera and Ekanayake 2008).

\section{Gender}

Only a quarter of the included publications $(n=27)$ reported gender-specific prevalence of dental pain. The prevalence estimated among males [34.2\% (95\% CI 29.1-39.2)] was marginally less than females [34.6\% (95\% CI 28-41.2)].

\section{Geographic location}

Only few studies were reported from Africa $(n=6)$, North America $(n=8)$, and Australia $(n=8)$ continents. However, studies from Africa had highest pooled prevalence of dental pain $(50.1 \%)$. The majority of the studies were from South America (pooled prevalence $=31 \%$ ) and Asia (pooled prevalence $=38.6 \%)($ Table 2$)$. Countries with publication of more than three were evaluated for pooled prevalence. Majority of the studies were from Brazil [30.7\% $(n=31$; CI 24.7-36.7)] followed by India [40.4\% ( $n=7$; CI 14-66.8)], Australia [21\% ( $n=6$; CI 11.2-30.8)], England [18.5\% 
Table 1 Summary characteristics of the included studies

\begin{tabular}{|c|c|c|c|c|c|c|}
\hline Author and year & Total & Continent & Age & ROB & Prevalence & Questionnaire \\
\hline (Carmichael et al. 1989) & 827 & $\mathrm{E}$ & 5 & $\mathrm{~L}$ & 21.77 & $\mathrm{P}$ \\
\hline (Treasure and Dever 1992) & 342 & $\mathrm{Au}$ & 5 & $\mathrm{~L}$ & 16.67 & $\mathrm{P}$ \\
\hline (Booth et al. 1992) & 227 & $\mathrm{E}$ & 3 & $\mathrm{~L}$ & 3.96 & $\mathrm{P}$ \\
\hline (Evans et al. 1995) & 1185 & $\mathrm{E}$ & 5 & $\mathrm{~L}$ & 12.66 & $\mathrm{P}$ \\
\hline (Slade et al. 1996) & 8568 & $\mathrm{Au}$ & $5-15$ & $\mathrm{~L}$ & 23.80 & $\mathrm{P}$ \\
\hline (Shepherd et al. 1999) & 589 & $\mathrm{E}$ & 8 & $\mathrm{~L}$ & 47.54 & $\mathrm{~S}$ \\
\hline (Honkala et al. 2001) & 27,765 & $\mathrm{E}$ & $12,14,16,18$ & $\mathrm{~L}$ & 30.99 & $\mathrm{~S}$ \\
\hline (Naidoo et al. 2001) & 1025 & Af & $8-10$ & $\mathrm{~L}$ & 87.80 & $\mathrm{~S}$ \\
\hline (Ananthakrishnan et al. 2001) & 150 & As & $5-12$ & $\mathrm{~L}$ & 1.33 & $\mathrm{U}$ \\
\hline (Vargas et al. 2002) & 560 & NA & $3-5$ & $\mathrm{~L}$ & 16.96 & $\mathrm{P}$ \\
\hline (De Barrêtto et al. 2004) & 601 & SA & $8-9$ & $\mathrm{~L}$ & 45.92 & $\mathrm{~S}$ \\
\hline (Nomura et al. 2004) & 169 & SA & $12-13$ & $\mathrm{~L}$ & 33.73 & $\mathrm{P}$ \\
\hline (Siegal et al. 2004) & 2555 & NA & $2-5$ & $\mathrm{~L}$ & 9.00 & $\mathrm{P}$ \\
\hline (Jiang et al. 2005) & 2662 & As & $11,13,15$ & $\mathrm{~L}$ & 41.28 & $\mathrm{~S}$ \\
\hline (Kiwanuka and Åstrøm 2005) & 614 & Af & $10-14$ & $\mathrm{~L}$ & 39.25 & $\mathrm{~S}$ \\
\hline (Ratnayake and Ekanayake 2005) & 576 & As & 8 & $\mathrm{~L}$ & 17.88 & $\mathrm{~S}$ \\
\hline (Robinson et al. 2005) & 174 & Af & 12 & $\mathrm{~L}$ & 36.21 & $\mathrm{~S}$ \\
\hline (Traebert et al. 2005) & 930 & SA & 12 & $\mathrm{~L}$ & 33.98 & $\mathrm{~S}$ \\
\hline (Vargas et al. 2005) & 2411 & NA & $\mathrm{KG}$ and 3 rd grade & $\mathrm{L}$ & 11.78 & $\mathrm{P}$ \\
\hline (Van Dijk et al. 2006) & 495 & NA & $9-13$ & M & 81.62 & $\mathrm{~S}$ \\
\hline (Bernabé et al. 2007) & 805 & SA & $11-12$ & $\mathrm{~L}$ & 43.35 & $\mathrm{~S}$ \\
\hline (Goes et al. 2007) & 1052 & SA & $14-15$ & $\mathrm{~L}$ & 33.65 & $\mathrm{~S}$ \\
\hline (Pau et al. 2007) & 187 & $\mathrm{E}$ & 12 & $\mathrm{~L}$ & 22.46 & $\mathrm{~S}$ \\
\hline (Shidara et al. 2007) & 366 & As & $6-16$ & M & 68.58 & $\mathrm{~S}$ \\
\hline (Bastos et al. 2008) & 339 & SA & 12 & $\mathrm{~L}$ & 12.09 & $\mathrm{~S}$ \\
\hline (Moura-Leite et al. 2008) & 549 & SA & 5 & $\mathrm{~L}$ & 24.95 & $\mathrm{P}$ \\
\hline (Pau et al. 2008) & 500 & As & $11-14$ & $\mathrm{~L}$ & 30.40 & $\mathrm{~S}$ \\
\hline (Perera and Ekanayake 2008) & 1218 & As & 15 & $\mathrm{~L}$ & 12.32 & $\mathrm{~S}$ \\
\hline (Campus et al. 2009) & 913 & $\mathrm{E}$ & Secondary school & $\mathrm{L}$ & 28.26 & $\mathrm{~S}$ \\
\hline (Jürgensen and Petersen 2009) & 594 & As & 12 & $\mathrm{~L}$ & 69.36 & $\mathrm{~S}$ \\
\hline (Versloot et al. 2009) & 652 & $\mathrm{E}$ & $2-5$ & M & 22.09 & $\mathrm{P}$ \\
\hline (Jamieson et al. 2010) & 301 & $\mathrm{Au}$ & $16-18$ & $\mathrm{~L}$ & 21.9 & $\mathrm{~S}$ \\
\hline (Lewis and Stout 2010) & 86,730 & NA & $1-17$ & $\mathrm{~L}$ & 10.70 & $\mathrm{P}$ \\
\hline (Peres et al. 2010) & 5815 & SA & 12 and 15 & $\mathrm{~L}$ & 25.54 & $\mathrm{~S}$ \\
\hline (Rupali et al. 2010) & 400 & As & $14-15$ & $\mathrm{~L}$ & 7.00 & $\mathrm{~S}$ \\
\hline (Areai et al. 2011) & 9098 & $\mathrm{Au}$ & $9-13$ & $\mathrm{~L}$ & 22.90 & $\mathrm{~S}$ \\
\hline (Barrêtto et al. 2011) & 174 & SA & $8-9$ & $\mathrm{~L}$ & 42.53 & $\mathrm{~S}$ \\
\hline (Da Silva et al. 2011) & 190 & SA & $11-12$ & M & 45.79 & $\mathrm{~S}$ \\
\hline (Dandi et al. 2011) & 2203 & As & 12 & $\mathrm{~L}$ & 71.40 & $\mathrm{~S}$ \\
\hline (Dogar et al. 2011) & 253 & $\mathrm{Au}$ & $2-4$ & M & 13.44 & $\mathrm{P}$ \\
\hline (Du et al. 2011) & 14,836 & $\mathrm{E}$ & $3-17$ & $\mathrm{~L}$ & 10.92 & $\mathrm{P} \& \mathrm{~S}$ \\
\hline (Figueiredo et al. 2011) & 835 & SA & $6-7$ & $\mathrm{~L}$ & 18.92 & $\mathrm{~S}$ \\
\hline (Jung et al. 2011) & 74,689 & As & $13-18$ & $\mathrm{~L}$ & 33.90 & $\mathrm{~S}$ \\
\hline (Jürgensen and Petersen 2011) & 612 & As & $11-13$ & $\mathrm{~L}$ & 70.26 & $\mathrm{~S}$ \\
\hline (Ravaghi et al. 2011) & 234 & As & $15-17$ & M & 26.07 & $\mathrm{~S}$ \\
\hline (Yuen et al. 2011) & 153 & NA & $10-18$ & M & 33.99 & $\mathrm{~S}$ \\
\hline (Leal et al. 2012) & 587 & SA & $6-7$ & $\mathrm{~L}$ & 21.81 & $\mathrm{~S}$ \\
\hline (Ravaghi et al. 2012) & 639 & As & $15-17$ & $\mathrm{~L}$ & 30.20 & $\mathrm{~S}$ \\
\hline (Sarri et al. 2012) & 965 & $\mathrm{E}$ & $15-16$ & $\mathrm{~L}$ & 7.36 & $\mathrm{~S}$ \\
\hline (Tsakos et al. 2012) & 292 & $\mathrm{E}$ & 5 & $\mathrm{~L}$ & 34.93 & $\mathrm{~S}$ \\
\hline
\end{tabular}


Table 1 (continued)

\begin{tabular}{|c|c|c|c|c|c|c|}
\hline Author and year & Total & Continent & Age & ROB & Prevalence & Questionnaire \\
\hline (Yusof and Jaafar 2012) & 132 & As & $11-12$ & $\mathrm{~L}$ & 43.94 & $\mathrm{~S}$ \\
\hline (Colares et al. 2013) & 970 & SA & $5-12$ & $\mathrm{~L}$ & 44.95 & $\mathrm{P}$ \\
\hline (de Lacerda et al. 2013) & 385 & SA & $7-8$ & $\mathrm{~L}$ & 31.69 & $\mathrm{~S}$ \\
\hline (Hu et al. 2013) & 305 & As & $7.6-9.3$ & M & 47.54 & $\mathrm{~S}$ \\
\hline (Lopes et al. 2013) & 4249 & SA & 12 & $\mathrm{~L}$ & 23.91 & $\mathrm{P}$ \\
\hline (Prasai Dixit et al. 2013) & 131 & As & $8-16$ & M & 31.30 & $\mathrm{~S}$ \\
\hline (Siqueira et al. 2013) & 814 & SA & $3-5$ & $\mathrm{~L}$ & 8.72 & $\mathrm{P}$ \\
\hline (Kumar et al. 2014) & 306 & As & $10-15$ & $\mathrm{~L}$ & 34.97 & $\mathrm{~S}$ \\
\hline (Mulu et al. 2014) & 147 & Af & $6-15$ & $\mathrm{~L}$ & 27.21 & $\mathrm{~S}$ \\
\hline (Noro et al. 2014) & 688 & SA & $11-15$ & $\mathrm{~L}$ & 31.69 & $\mathrm{~S}$ \\
\hline (Sousa et al. 2014) & 732 & SA & $3-5$ & $\mathrm{~L}$ & 6.42 & $\mathrm{P}$ \\
\hline (Ferreira-Júnior et al. 2015) & 7280 & SA & 5 & $\mathrm{~L}$ & 21.94 & $\mathrm{P}$ \\
\hline (Karibe et al. 2015) & 1415 & As & $11-15$ & $\mathrm{~L}$ & 9.96 & $\mathrm{~S}$ \\
\hline (Lemes et al. 2015) & 385 & SA & $2-4$ & $\mathrm{~L}$ & 9.87 & $\mathrm{P}$ \\
\hline (Ribeiro et al. 2015a) & 837 & SA & $3-5$ & $\mathrm{~L}$ & 31.66 & $\mathrm{P}$ \\
\hline (Schuch et al. 2015b) & 750 & SA & $8-10$ & $\mathrm{~L}$ & 33.33 & $\mathrm{~S}$ \\
\hline (Schuch et al. 2015a) & 1199 & SA & $8-12$ & $\mathrm{~L}$ & 35.70 & $\mathrm{~S}$ \\
\hline (Soares et al. 2015) & 101 & SA & $6-16$ & M & 57.43 & $\mathrm{~S}$ \\
\hline (U1 Hasan et al. 2015) & 152 & As & Primary school & M & 42.76 & $\mathrm{U}$ \\
\hline (Veiga et al. 2015) & 447 & $\mathrm{E}$ & $12-18$ & M & 30.65 & $\mathrm{~S}$ \\
\hline (Babo Soares et al. 2016) & 959 & $\mathrm{Au}$ & $6-17$ & $\mathrm{~L}$ & 35.77 & $\mathrm{~S}$ \\
\hline (Nguyen et al. 2016) & 556 & As & $8-10$ & $\mathrm{~L}$ & 33.45 & $\mathrm{~S}$ \\
\hline (Shekhawat et al. 2016) & 200 & As & $12-15$ & $\mathrm{~L}$ & 77.00 & $\mathrm{~S}$ \\
\hline (Kumar et al. 2016) & 800 & As & $12-15$ & $\mathrm{~L}$ & 10.13 & $\mathrm{~S}$ \\
\hline (Adeniyi and Odusanya 2017) & 414 & Af & $8-12$ & $\mathrm{~L}$ & 61.35 & $\mathrm{~S}$ \\
\hline (Andegiorgish et al. 2017) & 225 & Af & 12 & $\mathrm{~L}$ & 48.00 & $\mathrm{~S}$ \\
\hline (Barreto et al. 2017) & 1367 & SA & $6-7$ & $\mathrm{~L}$ & 50.84 & $\mathrm{~S}$ \\
\hline (Escoffié-Ramirez et al. 2017) & 1404 & NA & $6-12$ & M & 49.86 & $\mathrm{P}$ \\
\hline (Ghorbani et al. 2017) & 9875 & $\mathrm{Au}$ & $4-17$ & $\mathrm{~L}$ & 22.79 & $\mathrm{P}$ \\
\hline (Guskuma et al. 2017) & 1233 & SA & 12 & $\mathrm{~L}$ & 16.71 & $\mathrm{~S}$ \\
\hline (Kamran et al. 2017) & 753 & As & $4-17$ & $\mathrm{~L}$ & 10.23 & $\mathrm{~S}$ \\
\hline (Perazzo et al. 2017) & 768 & SA & 5 & $\mathrm{~L}$ & 23.44 & $\mathrm{P}$ \\
\hline (So et al. 2017) & 1407 & NA & $6 \mathrm{~m}-6 \mathrm{y}$ & $\mathrm{L}$ & 37.67 & $\mathrm{P}$ \\
\hline (Bashirian et al. 2018) & 988 & As & $7-12$ & $\mathrm{~L}$ & 71.26 & $\mathrm{~S}$ \\
\hline (Corrêa-Faria et al. 2018) & 563 & SA & $2-5$ & $\mathrm{~L}$ & 18.29 & $\mathrm{P}$ \\
\hline (Goettems et al. 2018) & 1196 & SA & $8-12$ & $\mathrm{~L}$ & 16.89 & $\mathrm{~S}$ \\
\hline (Hardy et al. 2018) & 3671 & $\mathrm{Au}$ & $10-16$ & $\mathrm{~L}$ & 4.09 & $\mathrm{~S}$ \\
\hline (Hu et al. 2018) & 4815 & As & $12-14$ & $\mathrm{~L}$ & 52.88 & $\mathrm{~S}$ \\
\hline (Mishra et al. 2018) & 210 & As & $5-15$ & M & 81.43 & $\mathrm{~S}$ and $\mathrm{P}$ \\
\hline (Misrohmasari et al. 2018) & 2377 & As & $12-14$ & $\mathrm{~L}$ & 13.93 & $\mathrm{~S}$ \\
\hline (Oliveira et al. 2018) & 9727 & SA & $13-17$ & $\mathrm{~L}$ & 59.49 & $\mathrm{~S}$ \\
\hline (Xu et al. 2018) & 1425 & As & $2-6$ & $\mathrm{~L}$ & 23.58 & $\mathrm{P}$ \\
\hline (Alzahrani 2019) & 92 & As & $12-16$ & M & 79.35 & $\mathrm{P}$ \\
\hline (Fernandes et al. 2019) & 306 & SA & $1-3$ & $\mathrm{~L}$ & 40.20 & $\mathrm{P}$ \\
\hline (Maharani et al. 2019) & 494 & As & $12-15$ & $\mathrm{~L}$ & 17.61 & $\mathrm{~S}$ \\
\hline (Miao et al. 2019) & 7022 & As & $11-18$ & $\mathrm{~L}$ & 38.49 & $\mathrm{~S}$ \\
\hline (Santos et al. 2019) & 1589 & SA & $8-10$ & $\mathrm{~L}$ & 51.54 & $\mathrm{~S}$ \\
\hline
\end{tabular}

$S A$ South America; NA North America; $A f$ Africa; As Asia; $A u$ Australia; $L$ Low; $M$ Moderate; $S$ self-reported; $P$ parent reported; $U$ Unclear 


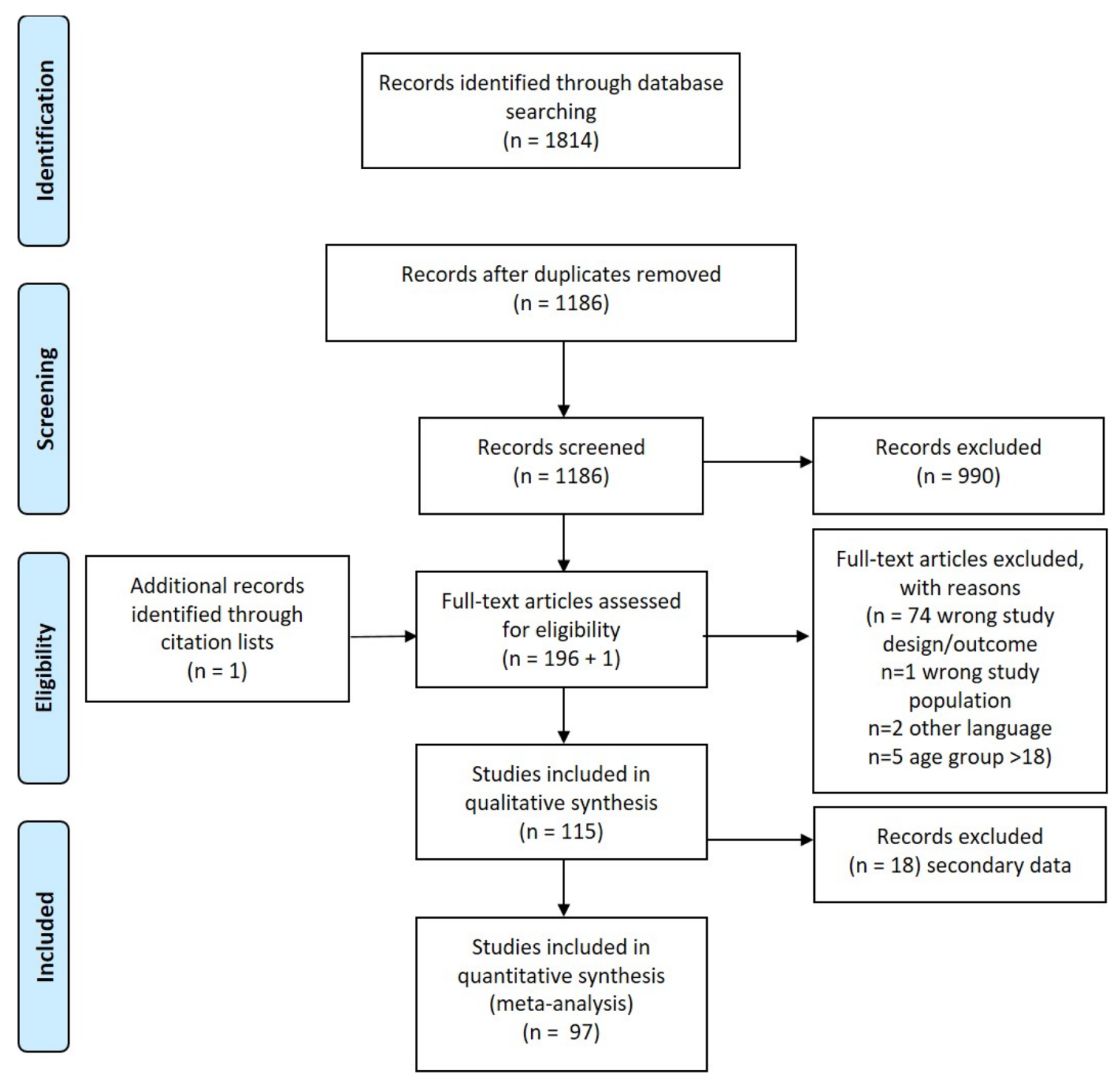

Fig. 1 PRISMA flowchart

$(n=5$; CI 7.9-29.2)], USA [21.8\% $(n=5$; CI 14.1-29.5)], China [41.3\% ( $n=4$; CI 27.6-55)], Pakistan [27.5\% $(n=3$; CI: 9.2-45.9)], and Iran [42.6\% ( $n=3$; CI 11.4-73.7)].

\section{Risk of bias}

The majority of the publications were in low-risk category $(n=82)$ while very few publications were at moderate risk $(n=15)$. The prevalence estimates for low and moderate ROB publications were 30.1 and $47.4 \%$ respectively (Table 2).

\section{Meta-analysis}

Heterogeneity was high among the included publications $\left(Q=49,063.12 ; P<0.001 ; \mathrm{df}=96\right.$ and $I^{2}=99.8 ; P<0.001$.
The random-effects model yielded a pooled prevalence of 32.7 (CI 29.6-35.9) (Fig. 2). Prevalence of dental pain in publications was reported as current, 1 week, 1 month, 3 , 6, 12 months and a lifetime experience. Accordingly, the pooled prevalence of dental pain was presented in Table 2 . No difference was seen in the trend of dental pain over the years (Coefficient: 0.005 ; 95\% CI $-0.001-0.011 ; P$-value: 0.101). (Fig. 3).

\section{Publication bias}

The funnel plot showed asymmetry $(p<0.001)$ (Fig. 4). 
Table 2 Subgroup analysis of the pooled estimates (Age, Continent, risk of bias, and dental pain recall)

\begin{tabular}{lll}
\hline Category & $\begin{array}{l}\text { Number of publica- } \\
\text { tions }\end{array}$ & $\begin{array}{l}\text { Estimate (confi- } \\
\text { dence interval) }\end{array}$ \\
\hline Age & & \\
$\leq 5$ years & 18 & $18.5(14.7-22.4)$ \\
$6-12$ years & 25 & $41.7(33.3-50.2)$ \\
$13-18$ years & 9 & $25.8(14-37.5)$ \\
Continent & & \\
Europe & 12 & $22.7(15.3-30.1)$ \\
Australia & 8 & $20.7(13.1-28.3)$ \\
Africa & 6 & $50.1(27-73.1)$ \\
Asia & 31 & $38.6(32.3-44.8)$ \\
North America & 8 & $31.3(21.2-41.5)$ \\
South America & 32 & $31(25.2-36.9)$ \\
Risk of Bias & & \\
Low & 82 & $30.1(26.7-33.5)$ \\
Moderate & 15 & $47.4(35.3-59.5)$ \\
Prevalence of dental pain as per the recall & \\
Current & 3 & $25.1(9.8-40.5)$ \\
1 week & 1 & 20.9 \\
1 month & 15 & $28(16.3-39.7)$ \\
3 months & 7 & $30.7(18.2-43.3)$ \\
6 months & 12 & $27.6(22.1-33.2)$ \\
1 year & 17 & $41.9(32.6-51.3)$ \\
Life time prevalence & 51 & $31.4(26.6-36.1)$ \\
\hline
\end{tabular}

\section{Discussion}

Dental pain can be a preventable and or treatable condition, although it may be self-limiting in few cases. In this review, we aimed to evaluate the pooled prevalence of dental pain among children and adolescents through subjective self/ proxy reports of dental pain in children and adolescents. A total of 97 studies constituted for the pooled estimates in this meta-analysis. The pooled prevalence has to be interpreted with caution due to high heterogeneity among the included publications. High heterogeneity could be due to the variability in disease prevalence which could have caused the dental pain, recall time interval for the prevalence of dental pain, geographic variation, access to care, social status, and availability of services. The overall pooled prevalence of dental pain was $32.7 \%$. Large population or national surveys reported prevalence in the range of $10.7-59.5 \%$ (FerreiraJúnior et al. 2015; Jung et al. 2011; Lewis and Stout 2010; Lopes et al. 2013; Misrohmasari et al. 2018; Oliveira et al. 2018; Peres et al. 2010). Studies from Africa reported high pooled prevalence $(50.1 \%)$ and lowest pooled prevalence was seen in Australia (20.7\%). Females showed marginally higher prevalence estimates than males. There was no significant difference in the trend of dental pain prevalence over the three decades. Among the included studies, age and gender-specific prevalence estimates have not been reported adequately.

There was no consensus in the recording of dental pain among the included studies. Studies have used single-item questions or questionnaires to evaluate the history of dental pain. Also, there was diversity in the recall time interval used across the studies viz., current, 1 week, 1 month, 3 , 6,12 , and a lifetime experience of dental pain. Few studies used more than one recall time interval which creates ambiguity in prevalence estimates. Nevertheless, we have used the maximal recall time interval from each study to calculate the overall prevalence of dental pain.

Dental pain could be due to a variety of reasons (eruption, exfoliation, carious teeth, dentinal hypersensitivity, or abscess) among children adolescents. The reason for the dental pain in most of the studies was not emphasized. Most of the reasons which cause dental pain may need treatment from a dental professional while reasons like eruption and exfoliation could be self-limiting. There could be overall inflation of the prevalence estimates due to the lack of emphasis on the etiology of the dental pain in the published studies.

Exclusion of non-English studies, lack of age specific prevalence estimates for substantial number of publications, and reason for dental pain are few of the limitations. Within the limits of this review, we could conclude that three out of ten children or adolescents could have experienced dental pain in the past. However, the prevalence estimates of dental pain may not indicate the exact treatment need due to reasons like self-limiting pain. It can be indicative of the burden of disease and its impact on children and adolescents. Such data may be useful for planning public health programs. Dental professionals should consider the fact that dental pain can be a common symptom among children and adolescents and is based on the subjective feeling of the individual.

Future studies on the prevalence of dental pain should use the the standard guidelines of "Strengthening the Reporting of Observational Studies in Epidemiology (STROBE)" and widely accepted criteria for the recall time interval for selfreported dental pain. Emphasis should be made on the reasons for dental pain to prevent overestimation of prevalence.

\section{Conclusion}

Considering the limitations of the study, two out of ten children below 5 years, four out of ten children between 6 and 12 years and three out of ten adolescents between 13 and 18 years would have experienced pain in the past. Overall, three out of ten children or adolescents might have experienced dental pain in the past. There was no difference in the 
Fig. 2 Forest plot of the prevalence of dental pain

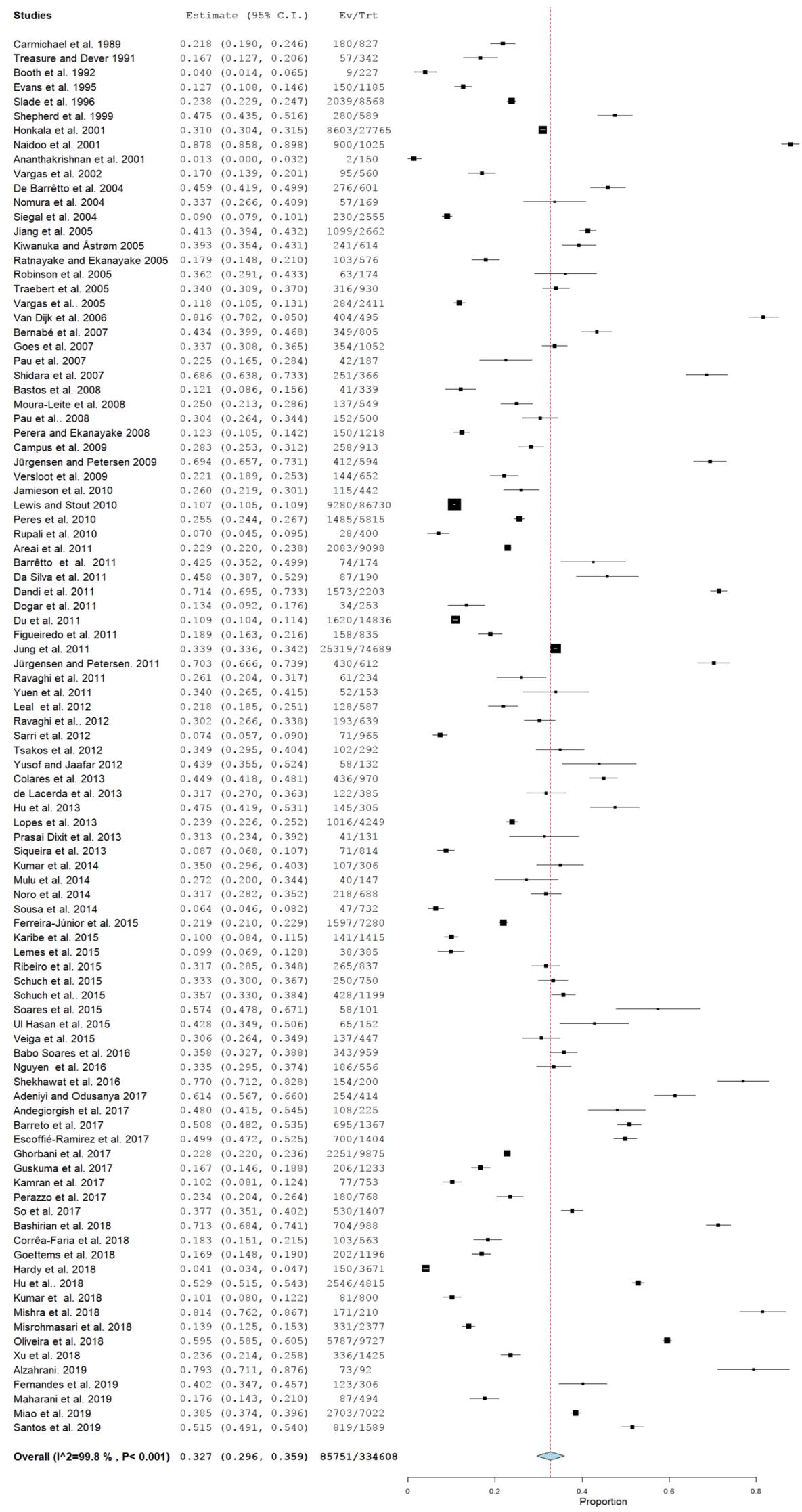


Fig. 3 Meta-regression to evaluate the trends of dental pain prevalence

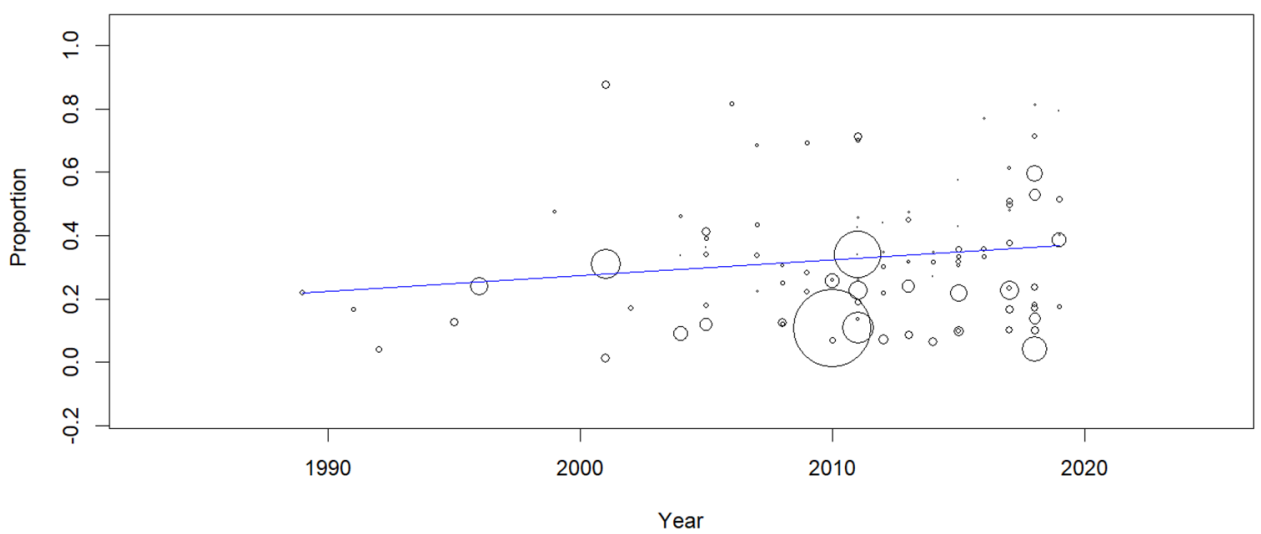

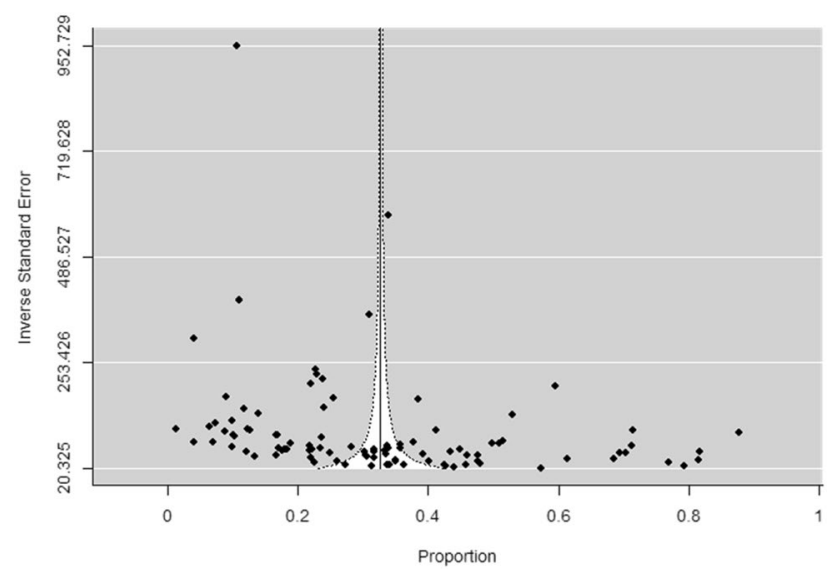

Fig. 4 Publication bias in prevalence estimates of dental pain with inverse standard error

pain prevalence between male and females. Studies from Africa reported highest pooled prevalence (50.1\%) with least being from Australia (20.7\%). Studies from India (40.4\%), China (41.3\%) and Iran (42.6\%) reported high pooled prevalence estimates of dental pain.

Acknowledgement Open access funding provided by Manipal Academy of Higher Education, Manipal.

\section{Compliance with ethical standards}

Conflicts of interest The authors declare that they have no conflict of interest.

Open Access This article is licensed under a Creative Commons Attribution 4.0 International License, which permits use, sharing, adaptation, distribution and reproduction in any medium or format, as long as you give appropriate credit to the original author(s) and the source, provide a link to the Creative Commons licence, and indicate if changes were made. The images or other third party material in this article are included in the article's Creative Commons licence, unless indicated otherwise in a credit line to the material. If material is not included in the article's Creative Commons licence and your intended use is not permitted by statutory regulation or exceeds the permitted use, you will need to obtain permission directly from the copyright holder. To view a copy of this licence, visit http://creativecommons.org/licenses/by/4.0/.

\section{References}

Adeniyi AA, Odusanya OO. Self-reported dental pain and dental caries among 8-12-year-old school children: an exploratory survey in Lagos. Nigeria Niger Postgrad Med J. 2017;24(1):37-433.

Al Agili DE. A systematic review of population-based dental caries studies among children in Saudi Arabia. Saudi Dent J. 2013;25(1):3-11.

Alzahrani AAH. Parent perspectives on perceived dental pain and dental caries in Saudi schoolchildren with intellectual disability. Spec Care Dent. 2019;39(3):310-8.

Ananthakrishnan S, Pani SP, Nalini P. A comprehensive study of morbidity in school age children. Indian Pediatr. 2001;38(9):1009-177.

Andegiorgish AK, Weldemariam BW, Kifle MM, Mebrahtu FG, Zewde HK, Tewelde MG, et al. Prevalence of dental caries and associated factors among 12 years old students in Eritrea. BMC Oral Health. 2017;17(1):169.

Areai DM, Thomson WM, Foster Page LA, Denny SJ, Crengle S, Clark TC, et al. Self-reported oral health, dental self-care and dental service use among New Zealand secondary school students: Findings from the Youth 07 study. N Z Dent J. 2011;107(4):121-6.

Al Ayyan W, Al Halabi M, Hussein I, Khamis AH, Kowash M. A systematic review and meta-analysis of primary teeth caries studies in Gulf Cooperation Council States. Saudi Dent J. 2018;30:175-82.

Babo Soares LF, Allen PL, Kingi J, Roberts-Thomson K, Bettiol S, Crocombe L. Changes in the oral health of the children of Dili, Timor Leste, between 2002 and 2014. Rural Remote Health. 2016;16(4):3853.

Barreto KA, Dos Prazeres LDKT, Lima DSM, Soares FC, Redivivo RMMP, da Franca C, et al. Factors associated with dental anxiety in Brazilian children during the first transitional period of the mixed dentition. Eur Arch Paediatr Dent. 2017;18(1):39-433.

Barrêtto ER, Paiva SM, Pordeus IA, e Ferreira E. Validation of a child dental pain questionnaire instrument for the self-reporting of toothache in Children. Pediatr Dent. 2011;33(3):228-32.

Bashirian S, Shirahmadi S, Seyedzadeh-Sabounchi S, Soltanian AR, Karimi-shahanjarini A, Vahdatinia F. Association of caries experience and dental plaque with sociodemographic 
characteristics in elementary school-aged children: a crosssectional study. BMC Oral Health. 2018;18(1):7.

Bastos JL, Peres MA, Peres KG, Araujo CLP, Menezes AMB. Toothache prevalence and associated factors: a life course study from birth to age 12 yr. Eur J Oral Sci. 2008;116(5):458-66.

Bernabé E, Tsakos G, Sheiham A. Intensity and extent of oral impacts on daily performances by type of self-perceived oral problems. Eur J Oral Sci. 2007;115(2):111-6.

Booth JM, Mitropoulos CM, Worthington HV. A comparison between the dental health of 3-year-old children living in fluoridated Huddersfield and non-fluoridated Dewsbury in 1989. Community Dent Health. 1992;9(2):151-7.

Campus G, Cagetti MG, Senna A, Spano G, Benedicenti S, Sacco G. Differences in oral health among Italian adolescents related to the type of secondary school attended. Oral Health Prev Dent. 2009;7(4):323-30.

Carmichael CL, Rugg-Gunn AJ, Ferrell RS. The relationship between fluoridation, social class and caries experience in 5-year-old children in Newcastle and Northumberland in 1987. Br Dent J. 1989;167(2):57-61.

Colares V, Franca C, Ferreira A, Amorim Filho HA, Oliveira MCA. Dental anxiety and dental pain in 5- to 12-year-old children in Recife. Brazil Eur Arch Paediatr Dent. 2013;14(1):15-9.

Corrêa-Faria P, Daher A, Freire MDCM, de Abreu MHNG, Bönecker M, Costa LR. Impact of untreated dental caries severity on the quality of life of preschool children and their families: a crosssectional study. Qual Life Res. 2018;27(12):3191-8.

Dandi K, Margabandhu S, Rao E. Dental pain as a determinant of expressed need for dental care among 12-year-old school children in India. Indian J Dent Res. 2011;22(4):611.

De Barrêtto EPR, Ferreira EF, Pordeus IA. Evaluation of toothache severity in children using a visual analogue scale of faces. Pediatr Dent. 2004;26(6):485-91.

DerSimonian R, Laird N. Meta-analysis in clinical trials. Control Clin Trials. 1986;7(3):177-88.

Dogar F, Kruger E, Dyson K, Tennant M. Oral health of pre-school children in rural and remote Western Australia. Rural Remote Health. 2011;11(4):1869.

Du Y, Knopf H, Zhuang W, Ellert U. Pain perceived in a national community sample of German children and adolescents. Eur J Pain. 2011;15(6):649-57.

Ekanayake L, Mendis R. Self reported use of dental services among employed adults in Sri Lanka. Int Dent J. 2002;52(3):151-5.

Escoffié-Ramirez M, Ávila-Burgos L, Baena-Santillan ES, AguilarAyala F, Lara-Carrillo E, Minaya-Sánchez M, et al. Factors Associated with Dental Pain in Mexican Schoolchildren Aged 6 to 12 Years. Biomed Res Int. 2017;2017:7431301.

Evans DJ, Rugg-Gunn AJ, Tabari ED. The effect of 25 years of water fluoridation in Newcastle assessed in four surveys of 5-year-old children over an 18-year period. Br Dent J. 1995;178(2):60-4.

Fernandes IB, Souto-Souza D, Primo-Miranda EF, Marques LS, Ramos-Jorge ML, Ramos-Jorge J. Perceived impact of dental pain on the quality of life of children aged 1-3 years and their families. Eur Arch Paediatr Dent. 2019;20(6):557-63.

Ferraz NKL, Nogueira LC, Pinhelro MLP, Marques LS, Ramos-Jorge ML, Ramos-Jorge J. Clinical consequences of untreated dental caries and toothache in preschool children. Pediatr Dent. 2014;36(5):389-92.

Ferreira-Júnior OM, Freire MDCM, da Moreira RS, Costa LR. Contextual and individual determinants of dental pain in preschool children. Community Dent Oral Epidemiol. 2015;43(4):349-56.

Figueiredo MJ, de Amorim RG, Leal SC, Mulder J, Frencken JE. Prevalence and severity of clinical consequences of untreated dentine carious lesions in children from a deprived area of Brazil. Caries Res. 2011;45(5):435-42.
Ghorbani Z, Peres MA, Liu P, Mejia GC, Armfield JM, Peres KG. Does early-life family income influence later dental pain experience? A prospective 14-year study. Aust Dent J. 2017;62(4):493-9.

Gibbs J, Hargreaves K. Acute and chronic orofacial and dental pain (Chap. 59). In: Wall and Melzack's textbook of pain. 6 edn. Elsevier Health Sciences; 2013. p. 803-814.

Goes PSA, Watt R, Hardy RG, Sheiham A. The prevalence and severity of dental pain in 14-15 year old Brazilian schoolchildren. Community Dent Health. 2007;24(4):217-24.

Goes PSA, Watt RG, Hardy R, Sheiham A. Impacts of dental pain on daily activities of adolescents aged 14-15 years and their families. Acta Odontol Scand. 2008;66(1):7-12.

Goettems ML, Shqair AQ, Bergmann VF, Cadermatori MG, Correa MB, Demarco FF. Oral health self-perception, dental caries, and pain: the role of dental fear underlying this association. Int $\mathrm{J}$ Paediatr Dent. 2018;28(3):319-25.

Gomes MC, Clementino MA, Pinto-Sarmento TCDA, Martins CC, Granville-Garcia AF, Paiva SM. Association between parental guilt and oral health problems in preschool children: A hierarchical approach. BMC Public Health. 2014;14(1):854.

Guskuma RC, Lages VA, Hafner MB, Rando-Meirelles MPM, Cypriano S, da Sousa MDLR, et al. Factors associated with the prevalence and intensity of dental pain in children in the municipalities of the campinas region. São Paulo Rev Paul Pediatr. 2017;35(3):322-30.

Hardy LL, Bell J, Bauman A, Mihrshahi S. Association between adolescents' consumption of total and different types of sugarsweetened beverages with oral health impacts and weight status. Aust N Z J Public Health. 2018;42(1):22-6.

Hobdell M, Petersen PE, Clarkson J, Johnson N. Global goals for oral health 2020. Int Dent J. 2003;53(5):285-8.

Honkala E, Honkala S, Rimpelä A, Rimpelä M. The trend and risk factors of perceived toothache among finnish adolescents from 1977 to 1997. J Dent Res. 2001;80(9):1823-7.

Hoy D, Brooks P, Woolf A, Blyth F, March L, Bain C, et al. Assessing risk of bias in prevalence studies: modification of an existing tool and evidence of interrater agreement. J Clin Epidemiol. 2012;65(9):934-9.

Hu J, Jiang W, Lin X, Zhu H, Zhou N, Chen Y, et al. Dental caries status and caries risk factors in students ages 12-14 years in Zhejiang. China Med Sci Monit. 2018;24:3670-8.

Hu X, Chen X, Fan M, Mulder J, Frencken JE. What happens to cavitated primary teeth over time? A 3.5-year prospective cohort study in China. Int Dent J. 2013;63(4):183-8.

Jamieson LM, Roberts-Thomson KF, Sayers SM. Risk indicators for severe impaired oral health among indigenous Australian young adults. BMC Oral Health. 2010;10:1.

Jiang H, Petersen PE, Peng B, Tai B, Bian Z. Self-assessed dental health, oral health practices, and general health behaviors in Chinese urban adolescents. Acta Odontol Scand. 2005;63(6):343-52.

Jung S-H, Watt RG, Sheiham A, Ryu J-I, Tsakos G. Exploring pathways for socio-economic inequalities in self-reported oral symptoms among Korean adolescents. Community Dent Oral Epidemiol. 2011;39(3):221-9.

Jürgensen N, Petersen PE. Oral health and the impact of socio-behavioural factors in a cross sectional survey of 12-year old school children in Laos. BMC Oral Health. 2009;9:29.

Jürgensen N, Petersen PE. Oral health behaviour of urban and semiurban schoolchildren in the Lao PDR. Community Dent Health. 2011;28(4):280-5.

Kamran R, Farooq W, Faisal MR, Jahangir F. Clinical consequences of untreated dental caries assessed using PUFA index and its covariates in children residing in orphanages of Pakistan. BMC Oral Health. 2017;17(1):108. 
Karibe H, Shimazu K, Okamoto A, Kawakami T, Kato Y, Warita-Naoi S. Prevalence and association of self-reported anxiety, pain, and oral parafunctional habits with temporomandibular disorders in Japanese children and adolescents: a cross-sectional survey. BMC Oral Health. 2015;15:8.

Kiwanuka SN, Åstrøm AN. Self-reported dental pain and associated factors in Ugandan schoolchildren. Nor Epidemiol. 2005; 15(2):175-82.

Kumar S, Badiyani BK, Kumar A, Dixit G, Sharma P, Agrawal S. Orofacial pain and quality of life in early adolescents in India. Int J Adolesc Med Health. 2016;30(2):20160037.

Kumar YS, Acharya S, Pentapati KC. Prevalence of dental pain and its relationship to caries experience in school children of Udupi district. Eur Arch Paediatr Dent. 2014;15(6):371-5.

de Lacerda JT, de Bem PM, Traebert J. Dental pain in Brazilian schoolchildren: a cross-sectional study. Int J Paediatr Dent. 2013;23(2):131-7.

Leal SC, Bronkhorst EM, Fan M, Frencken JE. Untreated cavitated dentine lesions: impact on children's quality of life. Caries Res. 2012;46(2):102-6.

Lemes MGC, Peixoto MDRG, Meneses IHCF, Freire MDCM. Dental pain and associated factors in 2 to 4-year-old children in Goiânia. Rev Bras Epidemiol. 2015;18(3):630-41.

Levine RS, Pitts NB, Nugent ZJ. The fate of 1587 unrestored carious deciduous teeth: A retrospective general dental practice based study from northern England. Br Dent J. 2002;193(2):99-103.

Lewis C, Stout J. Toothache in US children. Arch Pediatr Adolesc Med. 2010;164(11):1059-63.

Lopes RM, Domingues GG, Junqueira SR, de Araujo ME, Frias AC. Conditional factors for untreated caries in 12-year-old children in the city of São Paulo. Braz Oral Res. 2013;27(4):376-81.

Macfarlane TV, Blinkhorn AS, Davies RM, Kincey J, Worthington HV. Oro-facial pain in the community: prevalence and associated impact. Community Dent Oral Epidemiol. 2002;30(1):52-60.

Maharani DA, Kurniawan J, Agustanti A, Rosalien R, Rahardjo A, Cavalcanti AL. Diagnostic validity of self-perceived dental caries in indonesian young adolescents aged $12-15$ years. Pesqui Bras Odontopediatria Clin Integr. 2019;19(1).

Mansfield KE, Sim J, Jordan JL, Jordan KP. A systematic review and meta-analysis of the prevalence of chronic widespread pain in the general population. Pain. 2016;157(1):55-64.

Miao N-F, Wang T-C, Chang F-C, Lee C-H, Chi H-Y, Huang L-J, et al. Prevalence and association of pain experiences, medication literacy, and use of medication among children and adolescents in Taiwan. J Pediatr Nurs. 2019;46:e64-71.

Mishra A, Pandey RK, Chopra H, Arora V. Oral health awareness in school-going children and its significance to parent's education level. J Indian Soc Pedod Prev Dent. 2018;36(2):120-4.

Misrohmasari EAA, Hadnyanawati H, Kiswaluyo PB, Putri DE. Family characteristics on self-reported toothache among Indonesian children aged 12-14 years. Front Nurs. 2018;5(3):235-9.

Moura-Leite FR, Ramos-Jorge ML, Bonanato K, Paiva SM, Vale MP, Pordeus IA. Prevalence, intensity and impact of dental pain in 5-year-old preschool children. Oral Health Prev Dent. 2008;6(4):295-301.

Moure-Leite FR, Ramos-Jorge J, Ramos-Jorge ML, Paiva SM, Vale MP, Pordeus IA. Impact of dental pain on daily living of fiveyear-old Brazilian preschool children: prevalence and associated factors. Eur Arch Paediatr Dent. 2011;12(6):293-7.

Mulu W, Demilie T, Yimer M, Meshesha K, Abera B. Dental caries and associated factors among primary school children in Bahir Dar city: a cross-sectional study. BMC Res Notes. 2014;7:949.

Naidoo S, Chikte UM, Sheiham A. Prevalence and impact of dental pain in $8-10$-year-olds in the western Cape. SADJ. 2001;56(11):521-3.
Naidoo S, Sheiham A, Tsakos G. The relation between oral impacts on daily performances and perceived clinical oral conditions in primary school children in the Ugu District, Kwazulu Natal. South Africa SADJ. 2013;68(5):214-8.

Nguyen TT, Nguyen BBT, Nguyen MS, Olak J, Saag M. Effect of School Oral Health Promotion Programme on dental health and health behaviour in Vietnamese schoolchildren. Pediatr Dent J. 2016;26(3):115-21.

Nomura LH, Bastos JLD, Peres MA. Dental pain prevalence and association with dental caries and socioeconomic status in schoolchildren, Southern Brazil, 2002. Braz Oral Res. 2004;18(2):134-40.

Noro LRA, Roncalli AG, Mendes Júnior FIR, de Lima KC, Teixeira AKM. Toothache and social and economic conditions among adolescents in Northeastern Brazil. Cien Saude Colet. 2014;19(1):105-13.

de Oliveira MM, Andrade SSCDA, Stopa SR, Malta DC. Demand for health services or professionals among Brazilian adolescents according to the National School Health Survey 2015. Rev Bras Epidemiol. 2018;21:e180003.

Pau A, Baxevanos KG, Croucher R. Family structure is associated with oral pain in 12-year-old Greek schoolchildren. Int J Paediatr Dent. 2007;17(5):345-51.

Pau A, Khan SS, Babar MG, Croucher R. Dental pain and care-seeking in 11-14-yr-old adolescents in a low-income country. Eur J Oral Sci. 2008;116(5):451-7.

Pau AKH, Croucher R, Marcenes W. Prevalence estimates and associated factors for dental pain: a review. Oral Health Prev Dent. 2003;1(3):209-20.

Pentapati KC, Siddiq H, Yeturu SK. Global and regional estimates of the prevalence of root caries-Systematic review and metaanalysis. Saudi Dent J. 2019;31(1):3-15.

Pentapati KC, Yeturu SK, Siddiq H. Systematic review and meta-analysis of the prevalence of molar-incisor hypomineralization. J Int Oral Heal. 2017;9(6):243-50.

Perazzo MF, Gomes MC, Neves ÉT, Martins CC, Paiva SM, GranvilleGarcia AF. Oral health-related quality of life and sense of coherence regarding the use of dental services by preschool children. Int J Paediatr Dent. 2017;27(5):334-43.

Perera I, Ekanayake L. Factors influencing perception of oral health among adolescents in Sri Lanka. Int Dent J. 2008;58(6):349-55.

Peres MA, Peres KG, Frias AC, Antunes JLF. Contextual and individual assessment of dental pain period prevalence in adolescents: a multilevel approach. BMC Oral Health. 2010;10:20.

Prasai Dixit L, Shakya A, Shrestha M, Shrestha A. Dental caries prevalence, oral health knowledge and practice among indigenous Chepang school children of Nepal. BMC Oral Health. 2013;13(1):20.

Ratnayake N, Ekanayake L. Prevalence and impact of oral pain in 8-year-old children in Sri Lanka. Int J Paediatr Dent. 2005; 15(2):105-12.

Ravaghi V, Ardakan MMM, Shahriari S, Mokhtari N, Underwood M. Comparison of the COHIP and OHIP-14 as measures of the oral health-related quality of life of adolescents. Community Dent Health. 2011;28(1):82-8.

Ravaghi V, Underwood M, Marinho V, Eldridge S. Socioeconomic status and self-reported oral health in Iranian adolescents: The role of selected oral health behaviors and psychological factors. J Public Health Dent. 2012;72(3):198-207.

Ribeiro GL, Gomes MC, Granville-Garcia AF, de Lima KC, Martins CC, Paiva SM. The potential financial impact of oral health problems in the families of preschool children. Cienc e Saude Coletiva. 2016;21(4):1217-26.

Ribeiro GL, Gomes MC, de Lima KC, Martins CC, Paiva SM, Granville-Garcia AF. Work absenteeism by parents because of oral conditions in preschool children. Int Dent J. 2015;65(6):331-7. 
Robinson PG, Nalweyiso N, Busingye J, Whitworth J. Subjective impacts of dental caries and fluorosis in rural Ugandan children. Community Dent Health. 2005;22(4):231-6.

Ruff RR, Senthi S, Susser SR, Tsutsui A. Oral health, academic performance, and school absenteeism in children and adolescents: A systematic review and meta-analysis. J Am Dent Assoc American Dental Association. 2019;150:111-121.e4.

Rupali R, Kamal A, Kannan AT. Morbidity patterns among school students in east Delhi. Indian J Public Heal Res Dev. 2010;1(2):82-6.

Santos PS, Martins-Júnior PA, Paiva SM, et al. Prevalence of self-reported dental pain and associated factors among eight- to ten-year-old Brazilian school children. PLoS One. 2019;14(4):e0214990.

Sarri G, Evans P, Stansfeld S, Marcenes W. A school-based epidemiological study of dental neglect among adolescents in a deprived area of the UK. Br Dent J. 2012;213(10):E17.

Schuch H, Correa M, Torriani D, Demarco F, Goettems M. Perceived dental pain: determinants and impact on Brazilian Schoolchildren. J Oral Facial Pain Headache. 2015;29(2):168-76.

Schuch HS, dos Santos CF, Torriani DD, Demarco FF, Goettems ML. Oral health-related quality of life of schoolchildren: impact of clinical and psychosocial variables. Int J Paediatr Dent. 2015;25(5):358-65.

Seirawan H, Faust S, Mulligan R. The impact of oral health on the academic performance of disadvantaged children. Am J Public Health. 2012;102:1729-34.

Shekhawat KS, Chauhan A, Nordstroem M. Dental pain and its impact on quality of life among indigenous adolescents of Himalayas (Ladakh). India Indian J Dent Res. 2016;27(1):22-6.

Shepherd MA, Nadanovsky P, Sheiham A. The prevalence and impact of dental pain in 8-year-old school children in Harrow. England Br Dent J. 1999;187(1):38-41.

Shidara EK, McGlothlin JD, Kobayashi S. A vicious cycle in the oral health status of schoolchildren in a primary school in rural Cambodia. Int J Dent Hyg. 2007;5(3):165-73.

Siegal MD, Yeager MS, Davis AM. Oral health status and access to dental care for ohio head start children. Pediatr Dent. 2004;26(6):519-25.

Da Silva AN, Mendonça MH, Vettore MV. The association between low-socioeconomic status mother's Sense of Coherence and their child's utilization of dental care. Community Dent Oral Epidemiol. 2011;39(2):115-26.

Siqueira MB, Firmino RT, Clementino MA, Martins CC, GranvilleGarcia AF, Paiva SM. Impact of traumatic dental injury on the quality of life of Brazilian preschool children. Int J Environ Res Public Health. 2013;10(12):6422-41.

Slade GD. Epidemiology of dental pain and dental caries among children and adolescents. Community Dent Health. 2001;18(4):219-27.

Slade GD, Spencer AJ, Davies MJ, Burrow D. Intra-oral distribution and impact of caries experience among South Australian school children. Aust Dent J. 1996;41(5):343-50.

So M, Ellenikiotis Y, Husby H, Paz C, Seymour B, Sokal-Gutierrez K. Early childhood dental caries, mouth pain, and malnutrition in the Ecuadorian Amazon Region. Int J Environ Res Public Health. 2017;14(5):550.

Soares FC, Souto G, Lofrano M, Colares V. Anxiety related to dental care in children and adolescents in a low-income Brazilian community. Eur Arch Paediatr Dent. 2015;16(2):149-52.
Sousa RV, Clementino MA, Gomes MC, Martins CC, Granville-Garcia AF, Paiva SM. Malocclusion and quality of life in Brazilian preschoolers. Eur J Oral Sci. 2014;122(3):223-9.

Sterne JA, Egger M. Funnel plots for detecting bias in metaanalysis: guidelines on choice of axis. J Clin Epidemiol. 2001;54(10):1046-55.

Traebert J, de Lacerda JT, Fischer TK, Jinbo Y. Dental caries and orofacial pain trends in 12-year-old school children between 1997 and 2003. Oral Health Prev Dent. 2005;3(4):243-8.

Treasure ET, Dever JG. The prevalence of caries in 5-year-old children living in fluoridated and non-fluoridated communities in New Zealand. N Z Dent J. 1992;88(391):9-13.

Treede RD (2018) The International Association for the Study of Pain definition of pain: as valid in 2018 as in 1979, but in need of regularly updated footnotes. Pain Rep. 3(2):e643.

Tsakos G, Blair YI, Yusuf H, Wright W, Watt RG, Macpherson LMD. Developing a new self-reported scale of oral health outcomes for 5-year-old children (SOHO-5). Health Qual Life Outcomes. 2012;10:62.

Ul Hasan S, Tarique N, Hussain K, Dar UF. Prevalence of dental carries among school children. Pakistan J Med Heal Sci. 2015;9(4):1390-2.

Van Dijk A, McGrath PA, Pickett W, VanDenKerkhof EG. Pain prevalence in nine- to 13-year-old school children. Pain Res Manag. 2006;11(4):234-40.

Vargas CM, Macek MD, Goodman HS, Wagner ML. Dental pain in Maryland school children. J Public Health Dent. 2005;65(1):3-6.

Vargas CM, Monajemy N, Khurana P, Tinanoff N. Oral health status of preschool children attending Head Start in Maryland, 2000. Pediatr Dent. 2002;24(3):257-63.

Veiga NJ, Pereira CM, Ferreira PC, Correia IJ. Prevalence of dental caries and fissure sealants in a Portuguese sample of adolescents. PLoS ONE. 2015;10(3):e0121299.

Versloot J, Veerkamp JSJ, Hoogstraten J. The Dental Discomfort Questionnaire: the basis of a "Toothache Traffic Light". Eur Arch Paediatr Dent. 2009;10(2):67-70.

Xu M, Yuan C, Sun X, Cheng M, Xie Y, Si Y. Oral health service utilization patterns among preschool children in Beijing. China. BMC Oral Health. 2018;18(1):31.

Yuen HK, Wiegand RE, Hill EG, Magruder KM, Slate EH, Salinas CF, et al. Factors associated with toothache among African American adolescents living in rural South Carolina. Soc Work Public Health. 2011;26(7):695-707.

Yusof ZYM, Jaafar N. A malay version of the child oral impacts on daily performances (Child-OIDP) index: assessing validity and reliability. Health Qual Life Outcomes. 2012;10:63.

OpenMeta[Analyst]_CEBM @ Brown [Internet]. 1999. Available from: https://www.cebm.brown.edu/openmeta/index.html [Accessed on Aug 17 2018]

Publisher's Note Springer Nature remains neutral with regard to jurisdictional claims in published maps and institutional affiliations. 